\title{
SUstaiNability: a science communication website on environmental research
}

\author{
Teresita Gravina, Maurizio Muselli, Roberto Ligrone, and Flora Angela Rutigliano \\ Department of Environmental, Biological and Pharmaceutical Sciences and Technologies, University of Campania \\ Luigi Vanvitelli, Caserta, Italy \\ Correspondence to: Teresita Gravina (teresitagravina@gmail.com)
}

Received: 14 January 2016 - Discussion started: 19 January 2016

Revised: 30 April 2016 - Accepted: 6 May 2016 - Published: 29 August 2017

\begin{abstract}
Social networks enable anyone to publish potentially boundless amounts of information. However, such information is also highly prone to creating and/or diffusing mistakes and misunderstandings in scientific issues. In 2013 we produced a website (www.sunability.unina2.it) reporting on some research outputs from the University of Campania Luigi Vanvitelli (formerly the Second University of Naples, SUN), and shared it on Facebook and Twitter to analyse the effectiveness of these platforms in scientific dissemination. The study results suggest that (i) a regular update of the website stimulates the user's interest, (ii) Campania's citizens are more concerned with pollution problems than natural hazards, and (iii) direct involvement of researchers effectively enhances web-mediated scientific dissemination.
\end{abstract}

\section{Introduction}

Science communication is a dissemination of scientific knowledge to the general public, not involving formal educational activities. The central objective of science communication is producing one or more of the following responses (using the vowel analogy): awareness, enjoyment, interest, opinion, understanding (Burns et al., 2003). Essential to this purpose is the use of a language accessible to an audience with extremely diverse educational and cultural backgrounds.

The primary vehicle of scientific information is peerreviewed periodicals, generally focused on specific research areas and directed at well-circumscribed, specialized audiences. Primary scientific literature, therefore, is not directly accessible to the general public, and this tends to create a gap between the scientific community and wider society. Science magazines are a major source of scientific information for the general public, but their audience is generally restricted to people with a special interest in scientific issues.

A greater involvement of researchers in science dissemination, as well as the introduction of communication training in scientific degree courses, has been advocated on several occasions (see, for example, Brownell et al., 2013; Greenwood and Riordan, 2001; Leshner, 2003). Indeed, a survey by the European Commission (2007) has shown that European citizens consider scientists to be preferable to journalists as a source of information on scientific issues. In Italy, science communication is mainly performed by specialized journalists, and only recently (Italian Ministerial Decree, D.M., n. $47,2013)$ scientific and cultural dissemination has been officially included among third-mission activities of universities.

The world wide web has dramatically increased science visibility to the general public (Ynalvez et al., 2010); indeed, even popular science magazines have now opened websites. The media platforms are changing web users' way of interacting with news, events (Hermida et al., 2012; Kwak et al., 2010) and scientific information (Rigutto, 2015). Despite stimulating attention to science, the web does not foster scientific knowledge among the general public as much as one might expect, because not infrequently the information provided is unclear, incomplete or even utterly wrong; hence, it could cause a misunderstanding. A particularly effective example of a misunderstanding is the well-known case of Jade Helm 15 , a simple military exercise widely perceived by the general public as an imminent threat of civil war in the USA (Zollo et al., 2015a). Thanks to Web 2.0 and social networks, all users have the possibility to create and share information (Kaplan and Haenlein, 2010), but not all are able to assess 
the reliability of the source. Homogeneous user communities have arisen with well-focused finalities but with scarce mutual interaction (Zollo et al., 2015b). Not only does this restrain the flow of information between web user communities but it also feeds misinformation, an outcome recognized as a major threat to society by the World Economic Forum (Howell, 2013). As Lodhia (2012) emphasized, a major benefit from Web 2.0 to the dissemination of scientific information is in enabling the users to get information from researchers and interact with them, the latter being a key factor of effectiveness in communication. Bowman et al. (2015) highlighted the importance of researchers being present on social media and using it for outreaching and science dissemination in addition to contacting other scientists. A particularly important function of scientific communication is in environmental protection (Claussen et al., 2013) and prevision and/or prevention of natural disasters. Although essential for fostering responsible social behaviours towards natural resources and natural hazards, information on these issues among the general public is generally insufficient.

The University of Campania Luigi Vanvitelli (known as the Second University of Naples, SUN, from 1992 to 2016) is a state university established in Campania (southern Italy), an area highly exposed to natural risk including seismic (Italian Official Gazette, G.U., n. 108, 2006) and volcanic (Lirer et al., 2010) hazard, and also affected by well-known problems of pollution and waste mismanagement (Senior and Mazza, 2004). In 2013, we developed a website called SUstaiNability (http://www.sunability.unina2.it/), reporting some research outputs from the Department of Environmental, Biological and Pharmaceutical Sciences and Technologies (DiS$\mathrm{TABiF}$ ) of this university. The goal of this website was to inform the local population about the results of environmental research on the territory and to foster interaction between academia and society. SUstaiNability contents were shared through social networks (Facebook, Twitter) in order to assess (i) the effectiveness of these platforms in science dissemination, particularly towards the part of the population not attending formal educational activities; (ii) the level of interest of the target population (web users from Campania, particularly from Caserta); (iii) factors affecting SUstaiNability user activity on website and social networks. Here we report the results of this study.

\section{Materials and methods}

\subsection{Website and articles}

The SUstaiNability website, referred to as "the website" hereafter (Fig. 1), was hosted in the institutional internet domain of the university (www.sunability.unina2.it) in order to guarantee the reliability of contents. Since the main target of the website was local population, the language used was Italian but an English version of the home page was also provided. The website articles reviewed scientific papers published by DiSTABiF researchers on natural hazard and other environmental issues, as well as nutrition and health in the interval 2004-2012. All the publications considered were recorded in the Institutional Research Information System (https://iris.unina2.it/) and had links with Campania. The articles were written during the preparation of a master's degree project (Gravina, 2013) and were reviewed by one of the authors of each original paper (reference researcher, Table 1). The contents and template were designed to be understandable by people without specific scientific knowledge. Following a journalistic style, each article included a simple attention-grabbing title, an image from the original work and a summary outlining the conceptual sketch, purpose, main results and implications of the research, as well as links to the original publication, the email address of the reference researcher and the institutional web page (https: //iris.unina2.it/). Social media buttons (Facebook, Twitter, Linkedln, Google+) were available to share articles and post comments (Fig. 2). The association with social media permitted web users to interact with DiSTABiF researchers, although the SUstaiNability website itself did not use Web 2.0 technology.

Overall, 22 articles divided into 11 thematic areas and one in-depth section (Table 1 and Fig. 1) were published on the website in January-February 2013 (Table 1). For each thematic area we reviewed all relevant publications available at the time; hence the number of articles was not the same for all areas. Subsequently, two other articles were published but these were not used for the present study.

\subsection{Data collection}

Website articles have been shared on the Facebook page (https://www.facebook.com/SUNability/) and Twitter account (https://twitter.com/sunability). Visualizations, appreciations and shares have been monitored for each article, post (Facebook) and tweet (Twitter) for 28 days after publication (Table 1) because this was the duration of monitoring by Facebook insights in 2013. The monitoring activity lasted 2 months (within January-March 2013). Table 2 resumes the data obtained from monitoring and website tools (Joomla), Facebook (Facebook insights; https://www. facebook.com/help/search/?q=insights) and Twitter (Bitly; https://bitly.com/). Specifically, we looked for (1) demographic information (only for Facebook users) and geographical provenance (both Facebook and Twitter users); (2) reached users, i.e. the number of users who had seen the content associated with Facebook page; (3) visualizations, i.e. the number of article visualizations on website or numbers of post/tweet visualizations on social networks. Since in 2013 the number of tweet visualizations was not available, we replaced this parameter with the number of clicks on the link. We also looked for (4) subscribed users, i.e. the number of people who liked (Facebook) or followed (Twitter) the 
Table 1. Titles of website articles (in parenthesis, corresponding Italian titles reported on the website), thematic areas, reference researchers, publication dates (dd/mm/yyyy), identification numbers of website articles and references of original papers.

\begin{tabular}{|c|c|c|c|c|c|}
\hline Website articles & Thematic areas & Reference researchers & Dates of publication & Numbers & References \\
\hline $\begin{array}{l}\text { Marine diatoms as optical biosensors ( } \mathrm{Di} \text { - } \\
\text { atomee: Sensori ottici dai fondali oceanici) }\end{array}$ & Biotechnology (B) & M. De Stefano & $20 / 02 / 2013$ & 1 & De Stefano et al. (2009) \\
\hline $\begin{array}{l}\text { Tell me what you eat, I'll tell you who you are } \\
\text { (Dimmi cosa mangi e ti dirò chi sei) }\end{array}$ & $\begin{array}{l}\text { Physics for environmental and } \\
\text { cultural heritage }(\mathrm{PE})\end{array}$ & A. D'Onofrio & $18 / 02 / 2013$ & 2 & Lubritto and D'Onofrio (2009) \\
\hline $\begin{array}{l}\text { How much fear does the Mt Vesuvius erup- } \\
\text { tion elicit in the population? (Quanto fa paura } \\
\text { un'eruzione del Vesuvio?) }\end{array}$ & $\begin{array}{l}\text { Physics for environmental and } \\
\text { cultural heritage (PE) }\end{array}$ & C. Lubritto & $07 / 02 / 2013$ & 3 & Passariello et al. (2009) \\
\hline $\begin{array}{l}\text { Biochar, soil improver without greenhouse ef- } \\
\text { fect (Biochar, l'ammendante senza impatto } \\
\text { sull'effetto serra) }\end{array}$ & Greenhouse gases (GG) & S. Castaldi & $21 / 02 / 2013$ & 4 & Castaldi et al. (2011) \\
\hline $\begin{array}{l}\text { Waste management in Campania (La gestione } \\
\text { rifiuti in Campania) }\end{array}$ & Waste management (WM) & M. L. Mastellone & $06 / 02 / 2013$ & 5 & Mastellone et al. (2009) \\
\hline $\begin{array}{l}\text { Soil quality related to land uses (La qualità del } \\
\text { suolo in relazione all'uso del territorio) }\end{array}$ & Land management (LM) & F. A. Rutigliano & $21 / 01 / 2013$ & 6 & Marzaioli et al. (2010) \\
\hline $\begin{array}{l}\text { Intensive cultivation and soil quality (Agri- } \\
\text { coltura intensiva sotto serra e qualità del suolo) }\end{array}$ & Land management (LM) & R. D'Ascoli & $05 / 02 / 2013$ & 7 & Bonanomi et al. (2011) \\
\hline $\begin{array}{l}\text { A geographical information system for inte- } \\
\text { grated management of Domitio coastline (Un } \\
\text { SIC per la gestione integrata del litorale Domi- } \\
\text { tio) }\end{array}$ & Land management (LM) & D. Ruberti & $14 / 02 / 2013$ & 8 & D'Ambra et al. (2009) \\
\hline $\begin{array}{l}\text { Transport of radioactive substances from soil to } \\
\text { lettuce (Il passaggio di sostanze radioattive dal } \\
\text { suolo alla lattuga) }\end{array}$ & Pollution (Po) & F. Terrasi & $19 / 02 / 2013$ & 9 & Quinto et al. (2009) \\
\hline $\begin{array}{l}\text { Frogs sentinels of the state of environment ( } L o \\
\text { stato dell'ambiente visto da una rana) }\end{array}$ & Pollution (Po) & R. Ligrone & $25 / 01 / 2013$ & 10 & Maselli et al. (2010) \\
\hline $\begin{array}{l}\text { Traffic registered by pines (Il traffico registrato } \\
\text { dai pini) }\end{array}$ & Pollution (Po) & G. Battipaglia & $13 / 02 / 2013$ & 11 & Battipaglia et al. (2010) \\
\hline $\begin{array}{l}\text { How does city centre influence air quality in } \\
\text { neighbouring (Come il centro città influisce } \\
\text { sulla qualità dell'aria in periferia) }\end{array}$ & Pollution (Po) & P. Iovino & $08 / 02 / 2013$ & 12 & Iovino et al. (2009) \\
\hline $\begin{array}{l}\text { Air quality monitored by a lichen (La qualità } \\
\text { dell'aria monitorata da un lichene) }\end{array}$ & Pollution (Po) & S. Strumia & $11 / 02 / 2013$ & 13 & Sorbo et al. (2008) \\
\hline $\begin{array}{l}\text { Lead in soils of Volturno River low basin in } \\
\text { Caserta district (Il piombo nei suoli del bacino } \\
\text { del basso Volturno in provincia di Caserta) }\end{array}$ & Pollution (Po) & E. Coppola & $17 / 01 / 2013$ & 14 & Coppola et al. (2010) \\
\hline $\begin{array}{l}\text { Aspartic acid and mice memory (L'acido aspar- } \\
\text { tico e la memoria dei topi) }\end{array}$ & Ageing (A) & A. Usiello & $28 / 01 / 2013$ & 15 & Errico et al. (2011) \\
\hline $\begin{array}{l}\text { Phenylalanine Hydroxylase Deficiency distri- } \\
\text { bution in Campania (La distribuzione delle } \\
\text { iperfenilalaninemie in Campania) }\end{array}$ & Human diseases (HD) & A. Daniele & $31 / 01 / 2013$ & 16 & Daniele et al. (2006) \\
\hline $\begin{array}{l}\text { Micro RNA and thyroid cancer (I micro-RNA e } \\
\text { i tumori alla tiroide) }\end{array}$ & Human diseases (HD) & M. Grieco & $21 / 02 / 2013$ & 17 & Pacifico et al. (2010) \\
\hline $\begin{array}{l}\text { Volcano activity monitored by a simple diode } \\
\text { laser (Monitorare lo stato di un vulcano con un } \\
\text { semplice laser a diodo) }\end{array}$ & Natural risks (NR) & L. Gianfrani & $22 / 02 / 2013$ & 18 & Castrillo et al. (2004) \\
\hline $\begin{array}{l}\text { A statistical model for earthquake forecast (Un } \\
\text { modello statistico per la previsione dei terre- } \\
\text { moti) }\end{array}$ & Natural risks (NR) & E. Lippiello & $18 / 02 / 2013$ & 19 & Lippiello et al. (2012) \\
\hline $\begin{array}{l}\text { Mt Roccamonfina Volcano and its water (Il vul- } \\
\text { cano Roccamonfina e le sue acque) }\end{array}$ & Water resource (WR) & D. Tedesco & $23 / 02 / 2013$ & 20 & Cuoco et al. (2010) \\
\hline $\begin{array}{l}\text { Biofilm: one for all and all for one (Biofilm: uno } \\
\text { per tutti, tutti per uno) }\end{array}$ & Probiotics (Pr) & L. Muscariello & $23 / 01 / 2013$ & 21 & Muscariello et al. (2012) \\
\hline Plant evolution (Evoluzione delle piante) & In-depth article (D) & R. Ligrone & $04 / 02 / 2013$ & 22 & Ligrone et al. (2012) \\
\hline
\end{tabular}

SUstaiNability page/account; (5) appreciations, i.e. the number of users who appreciated the article on website (by expressing a vote), the number of users who liked an article posted on Facebook, or users who favoured a tweet on Twitter; (6) shares, i.e. the number of users who decided to share a website article. Shares on website were obtained by summing 
SUstaiNability

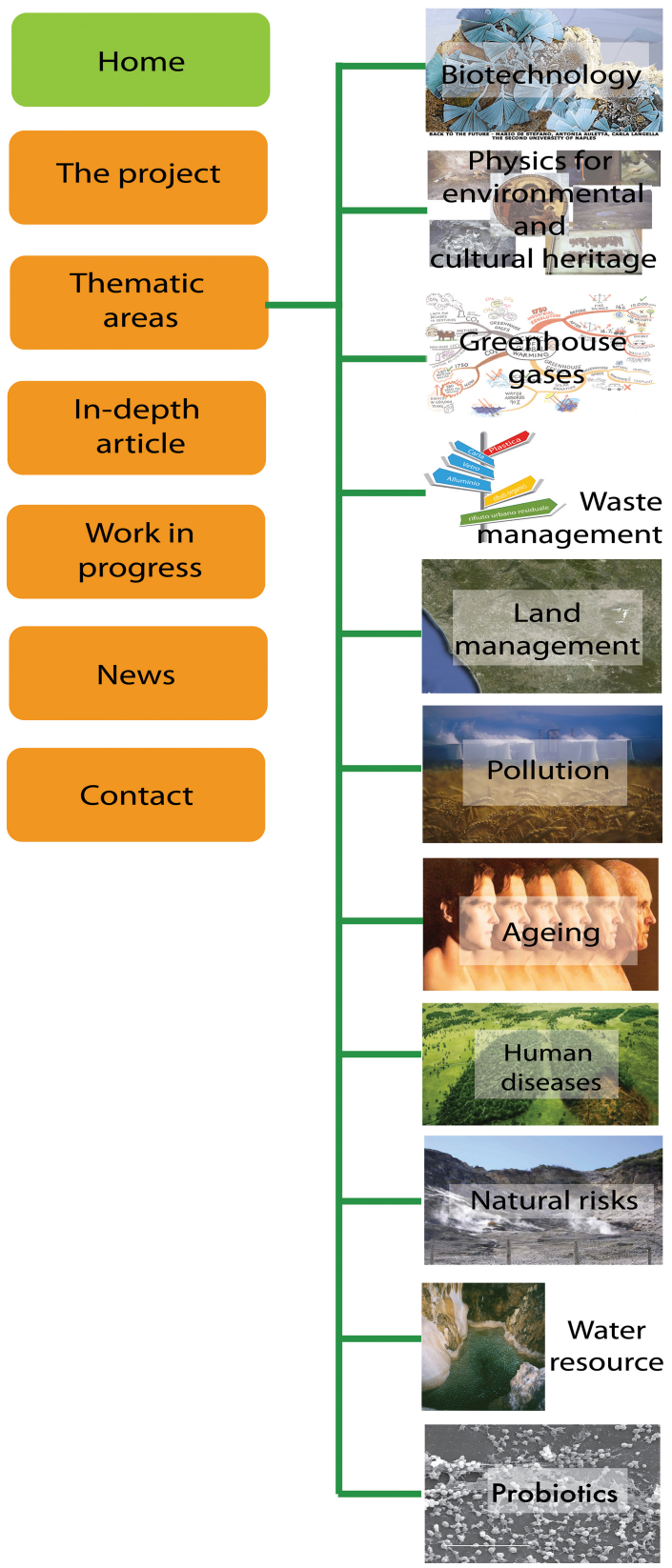

Figure 1. Map of the website (www.sunability.unina2.it).

shares and tweets registered by the social buttons included; Facebook and Twitter shares were evaluated as numbers of shares or retweets, respectively.

\subsection{Data analysis}

In order to assess the relative performance of the three platforms (website, Facebook and Twitter), we calculated the mean values and standard deviations of total visualizations, appreciations or shares obtained for each article. Moreover, to compare the performance of different thematic areas (as reported in Table 1), we calculated the mean values of visualizations, appreciations or shares for each thematic area and each platform. The data were analysed by a KolmogorovSmirnov normality test (SigmaPlot 12), and, where appropriate, normalized by $\log _{10}$ transformation. One-way analysis of variance (ANOVA; SigmaPlot 12), coupled with StudentNewman-Keuls test when required, was used to evaluate the significance $(P<0.05)$ of differences.

Article shares, assumed to be an indication of positive judgment, were analysed by principal component analysis (PCA, by SYN-TAX 5.0) applied to a matrix of 22 columns, one for each article, and 3 lines (for shares through each platform). The correlations between the axes of the biplot derived from PCA and possible regulating factors were assayed by Pearson coefficient (SigmaPlot 12).

\section{Results and discussion}

Geographical information from Facebook and Twitter showed that 95 and $77 \%$ of users reached by SUstaiNability posts or tweet, respectively, were resident in Italy. From Facebook insights, which provides detailed geographical and demographical data, we established that users were mainly from Campania (71\%), essentially from Naples $(50 \%)$ and Caserta $(40 \%)$ districts, with a remarkable majority of women $(61 \%$ vs. $39 \%)$ and an age mainly in the ranges 35-44 (31\%) and 25-34 years (30\%), i.e. post-school age. These data confirmed that the target audience had been reached.

During the observation period, 62491 users (on average 1042 day $^{-1}$ ) have been reached through Facebook. Comparable information for the other media is not available. This figure is in line with results by Bowman et al. (2015) reporting about 800 daily-reached users on the Facebook page for students of the Society of Environmental Toxicology and Chemistry (SETAC; http://www.facebook.com/ studentsofSETAC).

Significantly higher visualizations and appreciations (mean and total) were recorded for Facebook compared to the other two platforms (Fig. 3a, b). This is consistent with the analysis by Bowman et al. (2015), reporting that an average of $71 \%$ of social media users in the United States are on Facebook, followed by LinkedIn (22\%), Twitter (19\%) and Instagram $(17 \%)$. Facebook visualizations and appreciations were respectively 16 and $0.2 \%$ of the users reached by this platform. By contrast, the highest shares were obtained through the website (Fig. 3c). On the website page, social media share buttons are located beneath the text; hence, presumably the website users shared the article after reading it. Of the two social networks considered, a higher number of shares was recorded for Facebook (Fig. 3c). 


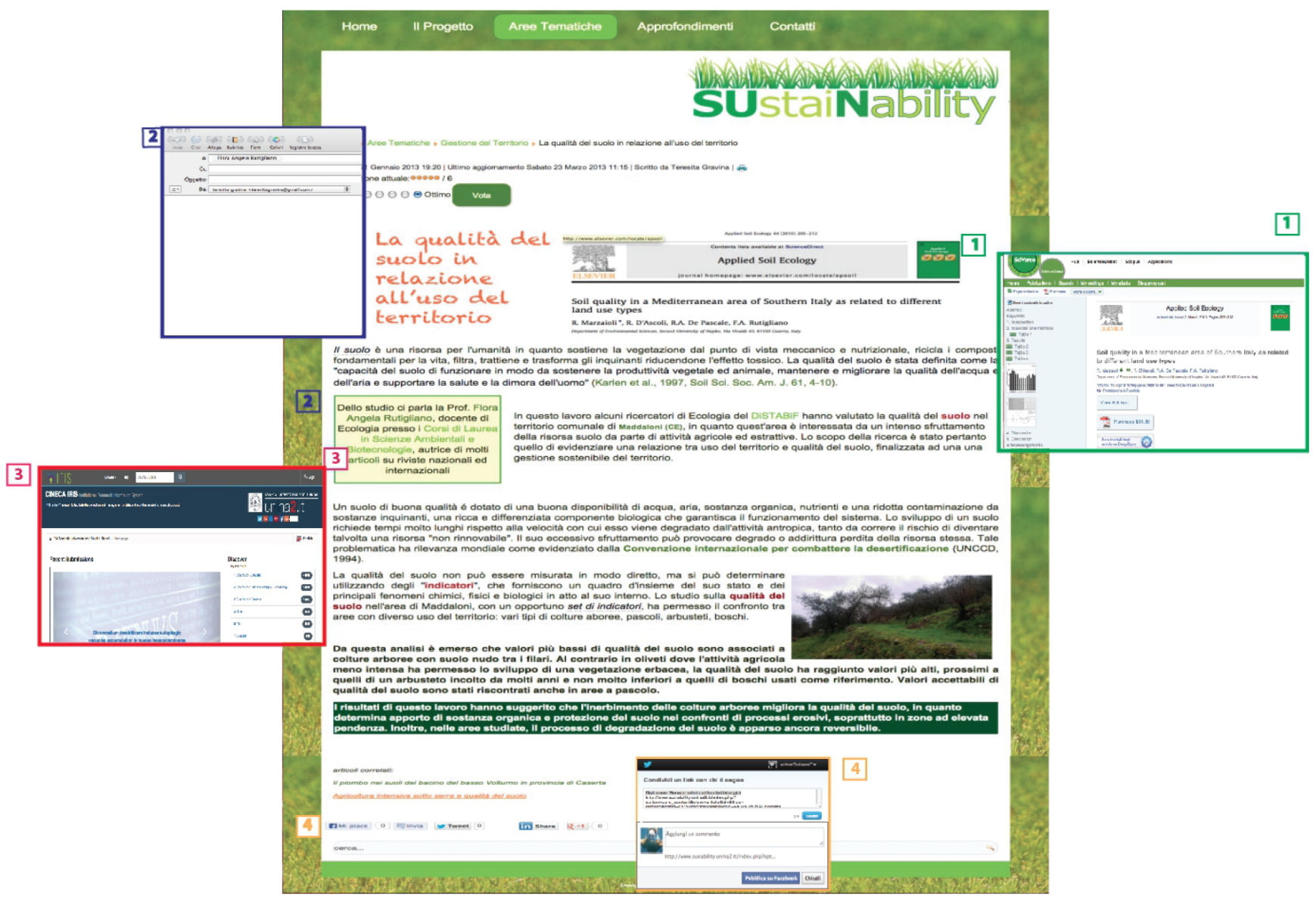

Figure 2. Web article template: (1) peer-reviewed journal web page, (2) reference researcher email, (3) reference researcher page on IRIS (https://iris.unina2.it/), (4) social buttons. As an example, the figure shows the article number 6 (Table 1) (http://www.sunability.unina2.it/ index.php?option=com_content\&view=article \&id=94:rutigliano\&catid=36:gestione-del-territorio $\&$ Itemid= $\$ 54)$.

Table 2. Tools used for the website and social network analysis and data collected during the monitoring period (the $\times$ indicates information availability). In parenthesis, specific terms used by different platforms.

\begin{tabular}{llll}
\hline & Website & Facebook & Twitter \\
\hline Tools & Joomla & Facebook insights & Bitly \\
Demographic information & & $\times$ & \\
Geographical provenance & $\times$ & $\times$ \\
Page visualizations & $\times$ & $\times$ (post $)$ & $\times$ (tweet $)$ \\
Reached users & & $\times$ & \\
Subscribed users & & $\times($ subscribed $)$ & $\times$ (follower $)$ \\
Appreciations & $\times($ vote $)$ & $\times($ like $)$ & $\times$ (favourited $)$ \\
Shares & $\times($ share and tweet) & $\times$ (share $)$ & $\times$ (retweet) \\
\hline
\end{tabular}

When we compared articles for visualizations (Fig. 4a), appreciations (Fig. 4b) and shares (Fig. 4c), we observed a pronounced diversity not only among the social media (as already shown in Fig. 3), but also among articles within the same thematic area (expressed by high standard deviations, limited to thematic areas containing several articles). This suggests that the thematic area was not the only factor af- fecting the article performance. A significant variability in visualizations (Fig. 4a) and appreciations (Fig. 4b) among thematic areas was recorded only for Twitter. Twitter users mainly visualized the in-depth article ( $D$, Fig. 4a) and mainly appreciated articles on the physics for environmental and cultural heritage thematic area (PE, Fig. 4b). In Facebook and website platforms, we observed a significant variation in the 
(a)

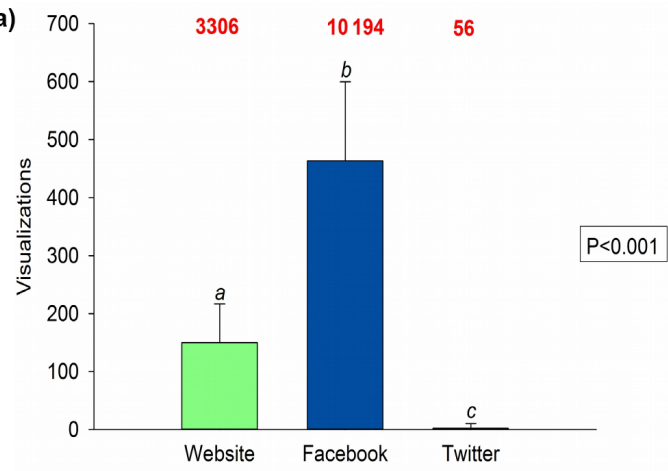

(b)

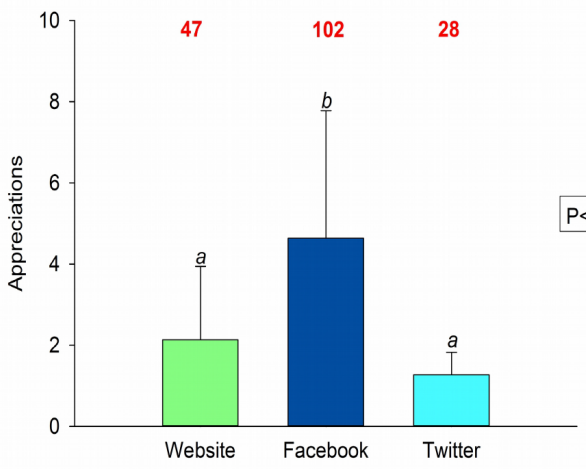

(c)

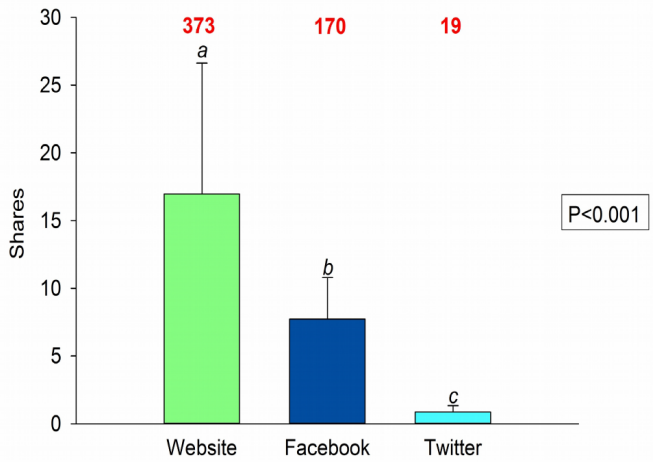

Figure 3. Mean values (and standard deviations) of visualizations (a), appreciations (b) and shares (c) of 22 articles in the website (www.sunability.unina2.it), Facebook (https://www.facebook. com/SUNability/) and Twitter (https://twitter.com/sunability). Red numbers at the top of each graph indicate total values for each media platform. Results of ANOVA are showed in the box on the right of each graph. Significant differences (evaluated by StudentNewman-Keuls test) between website, Facebook and Twitter are highlighted by different letters on the bars.

frequency of share among thematic areas (Fig. 4c). Facebook users shared the article on the probiotic thematic area $(\mathrm{Pr})$ less frequently than the others. Website users mainly shared articles from the pollution (Po) and greenhouse gases (GG) thematic areas, whereas they showed a lower sharing frequency for in-depth articles $(D)$. Articles related to natural risk (NR) obtained an intermediate number of shares in the website. (a)

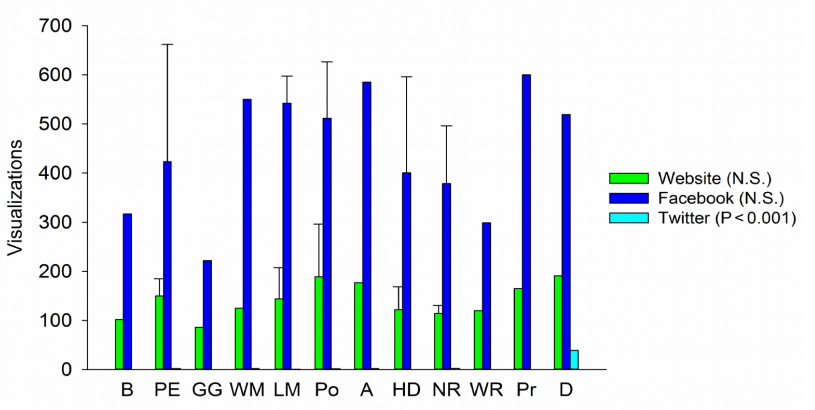

(b)

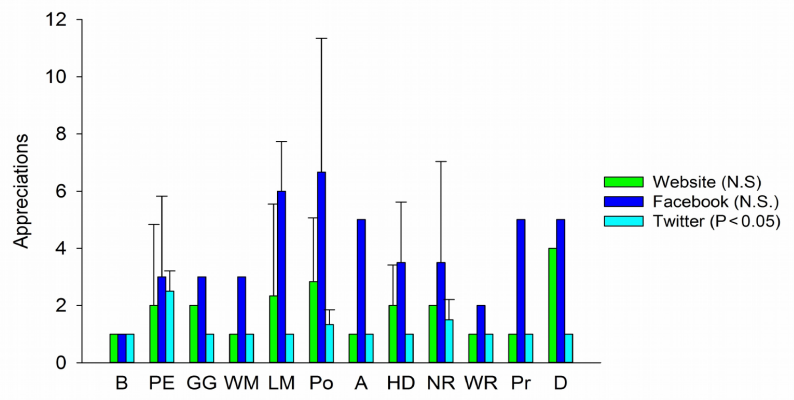

(c)

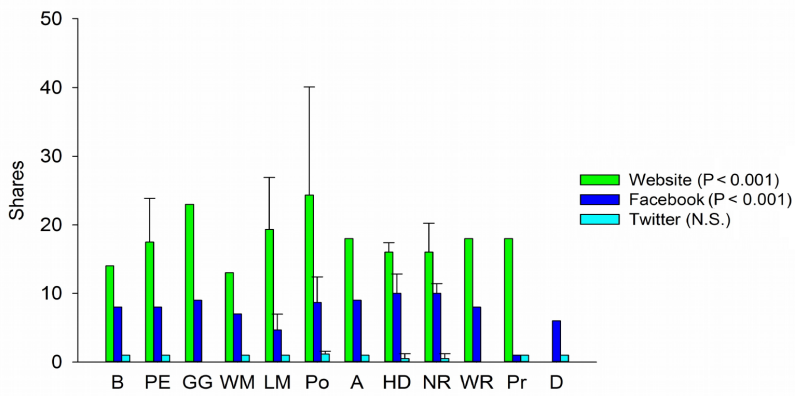

Figure 4. Mean values (and standard deviations) of visualizations (a), appreciations (b) and shares (c) for each thematic area in the website, Facebook and Twitter (for explanation of acronyms see Table 1). The significance of differences in visualization, appreciations and shares among thematic areas is indicated for each platform. N.S. means not significant.

The data obtained suggest that Campania's citizens are more worried about pollution events and related problems than natural hazards. This finding is in line with results by Ricci et al. (2013), reporting that the population living in Naples, i.e. very close to the critical volcanic area of Campi Flegrei, indicated a lack of public services, heavy traffic, waste, organized crime, poor social life and unemployment as their main problems, whereas only $0.5 \%$ of the respondents mentioned volcanoes and $1.7 \%$ earthquakes.

PCA applied to shares showed that the first two axes of the biplot accounted for the $78.43 \%$ of variance $(44.25 \%$ axis 1 ; $34.18 \%$ axis 2; Fig. 5). In the biplot, the articles clustered in distinct groups, circled with different colours in Fig. 5. The article in the yellow circle was published first, the articles in the blue circle last (Table 1). Axis 1 was negatively correlated with publication order $(r=-0.69 ; P<0.001)$. The articles published earlier have been visualized by web users 


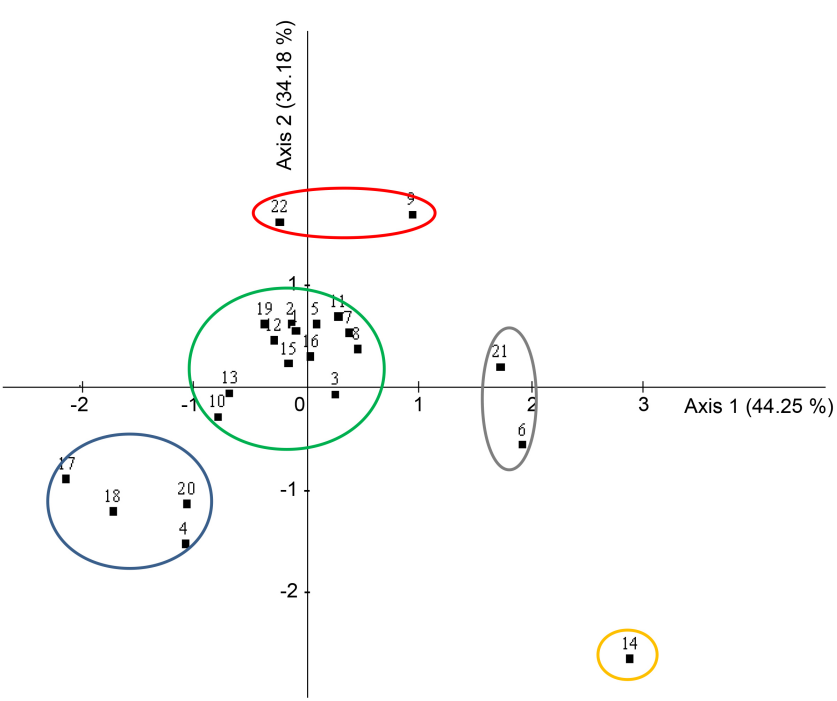

Figure 5. Principal component analysis (PCA) applied to shares of each article on the website, Facebook and Twitter (identification number of each article as in Table 1). The percentage of variance explained by each axis is reported in parenthesis. Articles clustering in distinct areas of the biplot are enclosed in circles of different colours.

more frequently than those published later, probably not only as an obvious consequence of longer circulation times but also because the users, when accessing a new article, were encouraged also to visualize older ones. This suggests that a frequent and regular updating of the web page enhances the users' interest.

The articles in blue circle had the highest number of undefined specialized terms, whereas those in the grey circle had the lowest. Axis 1 of the biplot was negatively correlated with the number of specialized terms not defined in the text or without links $(r=-0.42 ; P<0.05)$, suggesting that explicative notes and other aids enhance the user propensity to article sharing. Axis 2 was negatively correlated $(r=-0.47$; $P<0.05)$ with the inclusion of a clear link with issues likely to produce concern, such as health or the economy $(0=$ no link; $1=$ link). In contrast, no correlation was found between biplot axes and references to only one of the following topics: natural risk, human health, environment, technological transfer, Campania geographical sites (for each, $0=$ no reference; $1=$ clear reference). Axis 1 was correlated with share numbers on Facebook $(r=-0.83, P<0.001)$, the website $(r=0.51, P<0.05)$ and Twitter $(r=0.62, P<0.005)$. Axis 2 was correlated with share numbers in website $(r=-0.78$, $P<0.001)$ and Twitter $(r=0.65, P=0.001)$ as well as with total shares in the two social networks and website $(r=-0.76, P<0.001)$.

During the monitoring period, we also registered the number of subscriptions (likes or followers) on the social media page and account (Fig. 6). Overall, the SUstaNability page on Facebook had 281 subscribed users, while the Twitter ac-

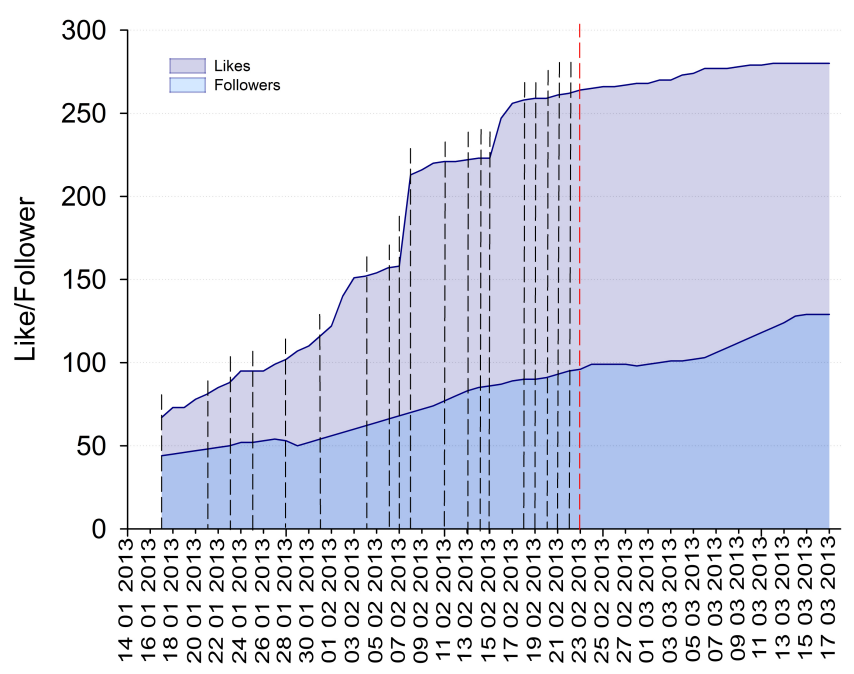

Figure 6. Comparison between the number of likes on the Facebook page and followers on Twitter during the monitored period. Vertical lines indicate the dates of publication (dd-mm-yyyy) of the articles on the website and social media (the red line marks the last publication date).

count had 129 followers, confirming Facebook as the most effective medium. As shown in Fig. 6, subscriptions on Facebook increased during article publication, but they did not change further after publication of the last article. In line with the observed correlation of axis 1 of the PCA biplot with the publication order, this supports the conclusion that a continuous updating of web pages helps to maintain users' interest. However, Twitter followers increased regularly throughout the monitored period.

In agreement with conclusions by other authors (Lodhia, 2012; Bowman et al., 2015), our results confirm that the web and social media are effective channels for scientific dissemination. However, whereas it is important that researchers directly contribute to the transfer of knowledge, it is also essential to make an effort on their side to produce clear and informative messages. This requires a major rethinking of the current approach, as the social media used by researchers to share their products (LinkedIn, ResearchGate, Accademia.edu) does not appear to make any effort to facilitate access to the general public.

The present analysis confirms the effectivity of www. sunability.unina2.it in enforcing a direct dialogue between academics and people living in the territory where the university is established. Future areas for prospective expansion include updating the website with Web 2.0 technologies in order to enhance direct interaction between DiSTABiF researchers and web users. 


\section{Conclusions}

The SUstaiNability audience was mainly from the Campania region and showed a strong interest in pollution issues but was relatively unconcerned with natural hazard. This is probably an effect of the great emphasis recently given by local and national media to pollution events and waste mismanagement problems in the area. However, Campania is also a territory strongly exposed to natural hazard; hence, the low level of interest expressed by citizens in this regard reflects poor information. This study calls for dissemination programmes to urgently improve knowledge, avoid misinformation and encourage responsible behaviour among Campania's citizens.

Our results suggest that, although social networks are useful for reaching web users and sharing news, websites are especially effective as a source of information on specific issues. Our analysis of data indicates that regularly updating scientific websites can be used to draw the attention of users. Moreover, research reports must maintain a delicate balance between correctness and clarity, hence omitting unnecessary details without missing essential points, and providing explanations wherever appropriate. Social media pages and accounts administered by academics could help the general audience to get reliable scientific information and would help researchers to promote their work outside the scientific community.

Data availability. Data used in this article have not been deposited to respect the privacy of users. Therefore, supplementary materials (provided separately) only include numerical data. On the contrary, demographic and geographical information on users cannot be made available because it involves people who are required to remain anonymous.

\section{The Supplement related to this article is available online at https://doi.org/10.5194/nhess-17-1437-2017- supplement.}

Author contributions. TG designed the website, administered the social media pages/account, wrote the first draft of website articles and collected data. FAR supervised the website contents. MM provided technical support for website maintenance. TG and FAR analysed the data and prepared the manuscript. RL revised the manuscript.

Competing interests. The authors declare that they have no conflict of interest.

Special issue statement. This article is part of the special issue "Effective Science Communication and Education in Hydrology and
Natural Hazards (NHESS/HESS inter-journal SI)". It is not associated with a conference.

Acknowledgements. The authors are very grateful to Giovanna Battipaglia, Simona Castaldi, Elio Coppola, Aurora Daniele, Rosaria D’Ascoli, Mario De Stefano, Antonio D’Onofrio, Livio Gianfrani, Michele Grieco, Pasquale Iovino, Eugenio Lippiello, Carmine Lubritto, Maria Laura Mastellone, Lidia Muscariello, Daniela Ruberti, Sandro Strumia, Dario Tedesco, Filippo Terrasi, Alessandro Usiello for their reviews of the website articles.

Edited by: Samuel Illingworth

Reviewed by: Rosa Vicari and one anonymous referee

\section{References}

Battipaglia, G., Marzaioli, F., Lubritto, C., Altieri, S., Strumia, S., Cherubini, P., and Cotrufo, M. F.: Traffic pollution affects treering width and isotopic composition of Pinus pinea, Sci. Total Environ., 408, 586-593, 2010.

Bonanomi, G., D’Ascoli, R., Antignani, V., Capodilupo, M., Cozzolino, L., Marzaioli, R., Puopolo, G., Rutigliano, F. A., Scelza, R., Scotti, R., Rao, M. A., and Zoina A.: Assessing Soil quality under intensive cultivation and tree orchards in Southern Italy, Appl. Soil Ecol., 47, 184-194, 2011.

Bowman, S. R., Biermans, G., Hicks, A., Jevtić, D. M., RodriguezGil, J. L., and Brockmeier, E. K.: A guide for using social media environmental science and a case study by the Students of SETAC, Environ. Sci. Eur., 27, 32, https://doi.org/10.1186/s12302015-0062-5, 2015.

Brownell, S. E., Price, J. V., and Steinman, L.: Science communication to the general public: why we need to teach undergraduate and graduate students this skill as part of their formal scientific training, J. Undergrad. Neurosci. Educ., 12, E6-E10, 2013.

Burns, T. W., O'Connor, D. J., and Stocklmayer, S. M.: Science Communication: A Contemporary Definition, Public. Underst. Sci., 12, 83-202, 2003.

Castaldi, S., Riondino, M., Baronti, S., Esposito, F. R., Marzaioli, R., Rutigliano, F. A., Vaccari, F. P., and Miglietta, F.: Impact of biochar application to a Mediterranean wheat crop on soil microbial activity and greenhouse gas fluxes, Chemosphere, 85, 4641471, 2011.

Castrillo, A., Casa, G., van Burgel, M., Tedesco, D., and Gianfrani, L.: First field determination of the ${ }^{13} \mathrm{C} /{ }^{12} \mathrm{C}$ isotope ratio in volcanic $\mathrm{CO}_{2}$ by diode-laser, Opt. Express., 12, 6515-6523, 2004.

Claussen, J. E., Cooney, P. B., Defilippi, J. M., Fox, G. M., Glaser, S. M., Hawkes, E., Hutt, C., Jones, M. H., Kemp, I. M., Lerner, A., Midway, S. R., Nesbit, S., Osborne-Gowey, J., Roberts, R., and Steward, C.: Science communication in a digital age: social media and the American fisheries society, Fisheries, 38, 359-362, 2013.

Coppola, E., Capra, G. F., Odierna, P., Vacca, S., and Buondonno, A.: Lead distribution as related to pedological features of soils in the Volturno River low Basin (Campania, Italy), Geoderma, 159, 342-349, 2010. 
Cuoco, E., Verrengia, G., De Francesco, S., and Tedesco, D.: Hydrogeochemistry of Roccamonfina volcano (Southern Italy), Environ. Earth. Sci., 61, 525-538, 2010.

D’Ambra, G., Ruberti, D., Verde, R., and Vigliotti, M.: La gestione integrata della fascia costiera: studio e correlazione di variabili a carattere biologico, ecologico, chimico e sedimentologico del litorale Domitio, in Provincia di Caserta, Atti della 13a Conferenza Nazionale ASITA, Bari, Italy, 1-4 December, 825-839, 2009.

Daniele, A., Cardillo, G., Pennino, C., Carbone, M. T., Scognamiglio, D., Correra, A., Pignero, A., Castaldo, G., and Salvatore, F.: Molecular Epidemiology of Phenylalanine Hydroxylase Deficiency in Southern Italy: a $96 \%$ Detection Rate with Ten Novel Mutations, Ann. Hum. Genet., 71, 85-193, 2006.

De Stefano, L., Rotiroti, L., De Stefano, M., Lamberti, A., Lettieri, S., Setaro, A., and Maddalena, P.: Marine diatoms as optical biosensors, Biosens. Bioelectron., 24, 1580-1584, 2009.

Errico, F., Nisticò, R., Napolitano, F., Bonito Oliva, A., Romano, R., Barbieri, F., Florio, T., Russo, C., Mercuri, N., and Usiello, A.: Persistent increase of d-aspartate in d-aspartate oxidase mutant mice induces a precocious hippocampal age-dependent synaptic plasticity and spatial memory decay, Neurobiol. Aging., 32, 2061-2074, 2011.

European Commission: Eurobarometer Science and the media: available at: http://ec.europa.eu/public_opinion/archives/ ebs/ebs_282_en.pdf (last access: 16 July 2017), 2007.

Gravina, T.: Redazione di un sito web per la divulgazione di prodotti della ricerca scientifica, Second University of Naples, MS Thesis, Italy, 151 pp., 2013.

Greenwood, M. R. C. and Riordan, D. G.: Civic scientist/Civic Duty, Sci. Commun., 23, 28-40, 2001.

Hermida, A., Fletcher, F., Korell, D., and Logan, D.: Share, like, recommend: decoding the social media news consumer, J. Stud., 13, 815-824, 2012.

Howell, W. L.: Digital wildfires in a hyperconnected world, Global Risks Report, Eighth Edn., World Economic Forum, Cologny, Geneva, Switzerland, 23-27, 2013.

Iovino, P., Polverino, R., Salvestrini, S., and Capasso, S.: Temporal and spatial distribution of BTEX pollutants in the atmosphere of metropolitan areas and neighbouring towns, Environ. Monit. Assess., 150, 437-444, 2009.

Italian Ministerial Decree, D.M., n. 47: Decreto autovalutazione, accreditamento iniziale e periodico delle sedi e dei corsi di studio e valutazione periodica, 2013.

Italian Official Gazette, G.U., n. 108: Criteri generali per l'individuazione delle zone sismiche e per la formazione e l'aggiornamento degli elenchi delle medesime zone, 2006.

Kaplan, A. M. and Haenlein, M.: Users of the world, unite! The challenges and opportunities of social media, Bus. Horizons, 53, 59-68, 2010.

Kwak, H., Lee, C., Park, H., and Moon, S.: What is Twitter, a social network or a news media?, Proceedings of the 19th international conference on world wide web, ACM, Railegh, NC, USA, 26-30 April, 591-600, 2010.

Leshner, A. I.: Public engagement with science, Science, 299, 997, https://doi.org/10.1126/science.299.5609.977, 2003.

Ligrone, R., Duckett, J. G., and Renzaglia, K. S.: Major transitions in the evolution of early land plants: a bryological perspective, Ann. Bot., 109, 851-871, 2012.
Lippiello, E., Marzocchi, W., de Arcangelis, L., and Godano, C.: Spatial organization of foreshocks as a tool to forecast large earthquakes, Sci. Rep., 2, 846, https://doi.org/10.1038/srep00846, 2012.

Lirer, L., Petrosino, P., and Alberico, I.: Hazard and risk assessment in a complex multi-source volcanic area: the example of the Campania Region, Italy, B. Volcanol., 72, 411-429, 2010.

Lodhia, S.: Web based social and environmental communication in the Australian minerals industry: an application of media richness framework, J. Clean. Prod., 25, 73-85, 2012.

Lubritto, C. and D'Onofrio, A.: Analisi elementali ed isotopiche per lo studio della dieta di popolazioni antiche, La diagnostica nei Beni Culturali, in: Moderni metodi di Indagine, edited by: Paolillo, L. and Giudicianni, I., Loghia Publishing \& Research, 141-154, 2009.

Marzaioli, R., D’Ascoli, R., De Pascale, R. A., and Rutigliano, F. A.: Soil quality in a Mediterranean area of Southern Italy as related to different land use types, Appl. Soil. Ecol., 44, 205-212, 2010.

Maselli, V., Polese, G., Rippa, D., Ligrone, R., Rastogi, R., and Fulgione, D.: Frogs, sentinels of DNA damage induced by pollution in Naples and the neighbouring Provinces, Ecotox. Environ. Safe, 73, 1525-1529, 2010.

Mastellone, M. L., Brunner, P. H., and Arena, U.: Scenarios of Waste Management for a Waste Emergency Area. A Substance Flow Analysis, J. Ind. Ecol., 13, 735-757, 2009.

Muscariello, L., Marino, C., Capri, U., Vastano, V., Marasco, R., and Sacco, M.: CcpA and three newly identified proteins are involved in biofilm development in Lactobacillus plantarum, J. Basic Microb., 52, 1-10, 2012.

Pacifico, F., Crescenzi, E., Mellone, S., Iannetti, A., Porrino, N., Liguoro, D., Moscato, F., Grieco, M., Formisano, S., and Leonardi, A.: Nuclear Factor-KB Contributes to Anaplastic Thyroid Carcinomas through Up-Regulation of miR-146a, J. Clinic Endocrinol. \& Metabol., 95, 1421-1430, 2010.

Passariello, I., Lubritto, C., D’Onofrio, A., Terrasi, F., Albore, L. C., and Talamo, P.: ${ }^{14} \mathrm{C}$ chronology of Avellino pumices eruption and timing of human reoccupation of the devastated region, Radiocarbon, 51, 803-816, 2009.

Quinto, F., Sabbarese, C., Visciano, L., Terrasi, F., and D'Onofrio, A.: ${ }^{137} \mathrm{Cs},{ }^{60} \mathrm{Co}$ and ${ }^{40} \mathrm{~K}$ uptake by lettuce plants in two distributions of soil contamination. J. Environ. Radioactiv., 100, 607612, 2009.

Ricci, T., Barberi, F., Davis, M. S., Isaia, R., and Nave, R.: Volcanic risk perception in the Campi Flegrei area, J. Volcanol. Geoth. Res., 254, 118-130, 2013.

Rigutto, C.: Twitter for Science Outreach. Conference: Science \& You, Nancy, France, https://doi.org/10.13140/RG.2.1.3514.9528, 4-6 June 2015.

Senior, C. and Mazza, A.: Italian "Triangle of Death" linked to waste management crisis, Lancet Oncol., 5, 525-527, 2004.

Sorbo, S., Aprile, G., Strumia, S., Castaldo Cobianchi, R., Leone, A., and Basile, A.: Trace element accumulation in Pseudovernía furfuracea (L.) Zopf. exposed in ltaly's so called Triangle of Death, Sci. Total Environ., 407, 647-658, 2008.

Ynalvez, M. A., Duque, R. B., and Shrum, W.: Shaping research in developing areas, in: World wide research: reshaping the sciences and humanities, edited by: Dutton, W. H. and Jeffreys, P. W., MIT Press, Cambridge, 325-342, 2010. 
Zollo, F., Bessi, A., Del Vicario, M., Scala, A., Caldarelli, G., Shekhtman, L., Havlin, S., and Quattrociocchi, W.: Debunking in a World of Tribes, arXiv preprint, 1510.04267, 2015a.
Zollo, F., Novak, P. K., Del Vicario, M., Bessi, A., Mozetic?, I., Scala, A., Cardarelli, G., and Quattrociocchi, W.: Emotional Dynamics in the Age of Misinformation, PLoS ONE, 10, e0138740, https://doi.org/10.1371/journal.pone.0138740, 2015b. 